\title{
Design, Synthesis and Antimycobacterial Activity of Dispiropyrrolidines Derivatives
}

Mohd Zaheen Hassan ${ }^{1,2}$, Mohamed Ashraf Ali ${ }^{2,3}$, Hasnah Osman ${ }^{1 *}$, Raju Suresh Kumar ${ }^{4}$ and Natarajan Arumugam $^{4}$

${ }^{1}$ School of Chemical Sciences, Universiti Sains Malaysia, Minden 11800, Penang, Malaysia

${ }^{2}$ Department of Pharmaceutical Chemistry, Alwar Pharmacy College, Alwar, Rajasthan, India

${ }^{3}$ Institute for Research in Molecular Medicine, Universiti Sains Malaysia, Minden 11800, Penang, Malaysia

${ }^{4}$ Department of Chemistry, College of Science, King Saud University, PO Box 2455, Riyadh 11451, Saudi Arabia

\begin{abstract}
In vitro anti-mycobacterial activities of dispiropyrrolidine derivatives along with their intermediates bisarylidene piperidones were investigated through high throughput screen. Our results revealed that dispiropyrrolidines possess promising activity against $M t b \mathrm{H}_{37} \mathrm{Rv}$. Compound 4g, 1-Methyl-4-(2,4-dichlorophenyl)pyrrolo-(spiro[2.3"]oxindole)spiro[3.3']-5'-(2,4-dichlorophenylmethylidene)piperidin-4'-one emerged as the most active antimycobacterial agent having $\mathrm{EC}_{50}$ of $2.46 \mu \mathrm{M}$ and MIC at $10 \mu \mathrm{M}$ against $\mathrm{MTB}-\mathrm{H}_{37} \mathrm{Rv}$.
\end{abstract}

Keywords: Spiro; Cytotoxicity; Antimycobacterial; Molecular docking

\section{Introduction}

Tuberculosis (TB) is a potentially fatal airborne infection caused by Mycobacterium tuberculosis ( $M t b)$ typically affecting the portal of entry of the body i.e., lungs but can infects other sites as well [1]. According to World Health Organization (WHO), around thirty-three percent world's population has been infected by TB bacterium and more than 1.5 million TB related deaths have been recorded in the year 2014 (Global tuberculosis report) [2]. Emergence and increasing prevalence of multiple drug-resistant (MDR) and extensively drug-resistant (XDR) TB has caused a disastrous global epidemic. Globally around 0.5 million new cases of MDR-TB and 0.2 million MDR-TB related deaths occurs annually. New clinical cases of XDR-TB are also on the rise making up about $10 \%$ of all MDR-TB cases $[3,4]$. The present treatment of TB covers around 10 drugs of different chemical classes approved by the FDA (Food and Drug Administration) of which isoniazid (INH), ethambutol (EMB), rifampin (RIF) and pyrazinamide (PZA) form the core of treatment regimens ( $1^{\text {st }}$ line drugs) [5]. However, despite of these powerful arsenals, the treatment of TB is still inadequate due to its extended treatment regimens, poor drug toxicity profiles, drug resistant $\mathrm{TB}$, limited chemical diversity and poor entry of drugs molecules into the cell [6]. Thus, the developments of safer and effective new class of anti-TB drugs are urgent priorities for the control of TB.

Heterocyclic compounds bearing isatin represent a potential structural motif possessing diverse pharmacological properties such as antibacterial, antifungal [7], anticancer [8] and antimycobacterial [9]. Moreover, the chemistry of spiro compounds has gained considerable momentum due to their synthetic and effective biological significance. For example, spiropyrrolo-oxindole is a core constituent of many naturally occurring alkaloids and biologically active compounds especially antimycobacterial (Figure 1) [10,11]. Our earlier studies have also confirmed that certain compounds bearing dispiropyrrolidine system possess significant antimycobacterial activity [12]. Encouraged by these observations and as a part of our research program on the synthesis of spiro compounds [13,14], in the present investigation we are reporting the in-vitro antimycobacterial activity of piperidone substituted dispiropyrrolidines. Synthesis and antiproliferative potentials of these compounds have also been reported earlier by our group [15].

\section{Experimental}

\section{Pharmacology}

The test samples were analyzed in vitro against Mycobacterium tuberculosis $\mathrm{H}_{37} \mathrm{Rv}\left(\mathrm{Mtb} \mathrm{H}_{37} \mathrm{Rv}\right)$ in a high throughput screen using an assay adapted from the microdilution AlamarBlue $(\mathrm{AB})$ broth assay as reported by Collins et al. [16]. All the operations of $M t b \mathrm{H}_{37} \mathrm{Rv}$ were conducted in accordance with the Biosafety Level 3 restraint [17]. The media was added to 96 microtitre well plates with the drugs followed by the addition of culture (diluted $\times 1000$ ) which were then serially diluted. Incubation was carried out at temperature of $37^{\circ} \mathrm{C}$ for $48 \mathrm{~h}$ then $\mathrm{AB}$ dye was added to the plates and incubation was further extended for another $24 \mathrm{~h}$. Controls was taken as a media and the solvent of same concentration used to dissolve the drugs. The plates were analyzed fluorometrically and the reduction of bacterial proliferation was calculated according to the manufacturer's formula.

\section{Cytotoxicity}

The cellular conversion of MTT (3-(4,5-dimethylthiazo-2-yl)2,5-diphenyl-tetrazolium bromide) into a formazan product was used to evaluate the cytotoxic activity $\left(\mathrm{IC}_{50}\right)$ of compounds against a mammalian Vero cells, using the Promega Cell Titer 96 non-radioactive cell proliferation assay [18]. The test compounds were dissolved in DMSO and serially diluted with complete medium to get the range of test concentration. DMSO concentration was kept at $0.1 \%$ in all the test compounds. Cell lines maintained in appropriate conditions were seeded in 96-well plates and treated with different concentrations of the test samples and incubated at $37^{\circ} \mathrm{C}, 5 \% \mathrm{CO}_{2}$ for $96 \mathrm{~h}$. MTT reagent was added to the wells and incubated for $4 \mathrm{~h}$; the dark blue formazan product formed by the cells was dissolved in DMSO in a safety cabinet and read at $550 \mathrm{~nm}$. \% inhibitions were calculated and plotted with the concentrations and used to calculate the $\mathrm{IC}_{50}$ values in micromoles.

*Corresponding author: Hasnah Osman, School of Chemical Sciences, Universit Sains Malaysia, Minden 11800, Penang, Malaysia, E-mail: ohasnah@usm.my

Received June 30, 2016; Accepted July 11, 2016; Published July 15, 2016

Citation: Hassan MZ, Ali MA, Osman H, Kumar RS, Arumugam N (2016) Design Synthesis and Antimycobacterial Activity of Dispiropyrrolidines Derivatives. Med chem (Los Angeles) 6: 486-491. doi:10.4172/2161-0444.1000387

Copyright: (c 2016 Hassan MZ, et al. This is an open-access article distributed under the terms of the Creative Commons Attribution License, which permits unrestricted use, distribution, and reproduction in any medium, provided the original author and source are credited. 
<smiles>COc1ccc2c(c1)[C@]1(CCN(C)C1)C(=O)N2</smiles>

(-)-Horsfiline<smiles>CC(C)C[C@H]1NCC[C@]12C(=O)Nc1cc(O)ccc12</smiles>

$(+)$-Elacomine<smiles>CC(C)=CC1N2C(=O)C3CCCN3C(=O)C2CC12CCCC2</smiles>

(-)-Spirotryprostatin B

Figure 1: Some representative structures of naturally occurring spiropyrrolidine-oxindole alkaloids.

\section{Molecular docking studies}

The most active antitubercular compound $\mathbf{4 g}$ was docked into the active site of enzyme type II dehydroquinase (DHQase) using Glide (version 5.7, Schrödinger, LLC, New York, NY, 2011). The crystal structure of $M t b$ Type II DHQase (PDB ID: 1H0R) was retrieved from the RCSB Protein Data Bank (PDB) and was preprocessed, refined and minimized using Protein Preparation Wizard. The ligands were optimized using LigPrep to obtain the lowest energy state. Glide program was used for the docking study, treating the ligand with fully flexible all atom depiction and receptor with rigid grid representation. van der Waals radii scaling factor of 1.00 with a partial charge cut-off of less than $0.25 \mathrm{e}$ was applied for the generation of grid.

\section{Results and Discussion}

\section{Antimycobacterial activity}

All the synthesized compounds 4a-n including their intermediates 3a-n (Scheme 1) were assessed for their in vitro inhibitory activity against the Mycobacterium tuberculosis $\mathrm{H}_{37} \mathrm{R}_{\mathrm{V}}\left(M T B-\mathrm{H}_{37} \mathrm{Rv}\right)$ by BTG (BacTiter-Glo ${ }^{\mathrm{Tm}}$ ) Microbial Cell Viability assay which is a quantitative ATP assay for bacteria utilising luciferase generation as end-point detection. The results of the antitubercular screening of compounds are presented in Table 1 and compared against five standard anti-TB drugs. Among the twenty-eight compounds tested, only five compounds $\mathbf{3 g}$, $\mathbf{4 d}, \mathbf{4 f}, \mathbf{4 g}$, and $\mathbf{4 k}$ showed promising results with MIC value $\leq 25 \mu \mathrm{M}$ comparable to cycloserine $(25 \mu \mathrm{M})$ and pyrimethamine $(100 \mu \mathrm{M})$. But, not a single compound is as potent as standard drugs isoniazide $(0.31$ $\mu \mathrm{M})$ and amikacin $(0.16 \mu \mathrm{M})$. Compounds $3 \mathbf{g}$ and $\mathbf{4 g}$ were found to be most active compounds against $M T B-\mathrm{H}_{37} \mathrm{Rv}$ with $\mathrm{MIC}$ of $10 \mu \mathrm{M}$. The inhibitory concentrations $\mathrm{EC}_{50}$ and $\mathrm{EC}_{90}$ values for compound $\mathbf{3 g}$ were found to be $4.46 \mu \mathrm{M}$ and $8.42 \mu \mathrm{M}$, respectively whereas for compound $4 \mathrm{~g}$, it was $2.46 \mu \mathrm{M}$ and $5.42 \mu \mathrm{M}$, respectively (manifold higher than cycloserine and pyrimethamine). This clearly indicates that cyclization of arylidene into spiropyrrolidine nucleus resulted into enhanced activity. Compounds $\mathbf{4 d}, \mathbf{4 f}$, and $\mathbf{4 k}$ showed moderate inhibitory activity against $M T B-\mathrm{H}_{37} \mathrm{Rv}$ with MICs $25 \mu \mathrm{M}$. The substituents on the aromatic ring played a key role in varying the efficacy of antimycobacterial activity. The general structure-activity relationship (SAR) of these compounds showed that the derivatives having electron-withdrawing groups were more active than derivatives having electron-releasing groups. Among the lipophilic electron-withdrawing groups $(+\sigma /+\pi)$ only ortho and para substituted chloro and fluoro derivatives more active. On the other hand, ortho, para disubstitutions with chloro group at the phenyl ring resulted into higher inhibitory activity against MTB.

The hydrophobic character of a bioactive compound strongly affects its biological properties. Thus quantitation of hydrophobicity of compounds is of importance in drug design studies. The logarithm of partition coefficient $(\log \mathrm{P})$ is widely used as an index of hydrophobicity [19]. Therefore, clog P of each compounds (except $\mathbf{3 h}$ and $\mathbf{4 h}$ ) were calculated using the commercially available program ChemDraw Ultra 11.0 (Table 1). When a regression analysis was carried out on the plots of the $\log 1 / \mathrm{C}$ values in terms of the corresponding partition coefficients (clog P) for each compounds, a positive but weak correlations having $r^{2}=0.0692-0.1906$ were obtained (Figure 2). The linear relationship between $\log 1 / \mathrm{C}$ and $\operatorname{cog} \mathrm{P}$ has been best fitted. The following general regression equation was therefore applied. $\mathrm{Y}=\mathrm{Ax}+\mathrm{B}$; where, $\mathrm{Y}=\log 1 / \mathrm{C}$; $\mathrm{X}=$ Calculated $\log \mathrm{P}$; and $\mathrm{A}$ and $\mathrm{B}$ are constants. These non-significant correlation results may be explained by the literature which revealed that lipophilicity of the molecule which aids cellular penetration is not the only determinant indeed, optimal drug-receptor interaction also influence their effects [20]. Therefore, further studies regarding quantitative structure-activity relationships (QSARs) considering other descriptors are in progress in our laboratory.

Since, none of the clinically available anti-TB drugs are perfect and most of them are suffering from chronic and acute adverse effects therefore, the present study also focuses on the toxicity studies of the synthesized compounds. The cytotoxic effects $\left(\mathrm{IC}_{50}\right)$ of the compounds were evaluated against the VERO cells. All the tested compounds showed $\mathrm{IC}_{50}$ values more than $62.5 \mu \mathrm{g} / \mathrm{mL}$. These high values clearly demonstrate that all the compounds were safer and effective antitubercular agents [21].

\section{Molecular docking studies}

Enzyme type II dehydroquinase (DHQase) from the shikimate pathway is essential for $M t b$ survival which catalyses the conversion of 3-dehydroquinate into 3-dehydroshikimate. Moreover, this pathway is absent in mammals, thus type II DHQase is a validated safer target for the development of new antimycobacterial agents [21]. Therefore, to gain further evidence regarding the antimycobacterial potential of compound $\mathbf{4 g}$, a molecular docking study was carried out in Glide 5.7 program (Schrödinger Inc. USA). The best binding modes of compound $\mathbf{4 g}$ in the active site of Type II DHQase are presented in Figures 3 and 4. Type II DHQase active site composed of Pro11, Asn12, Leu13, Arg19, 


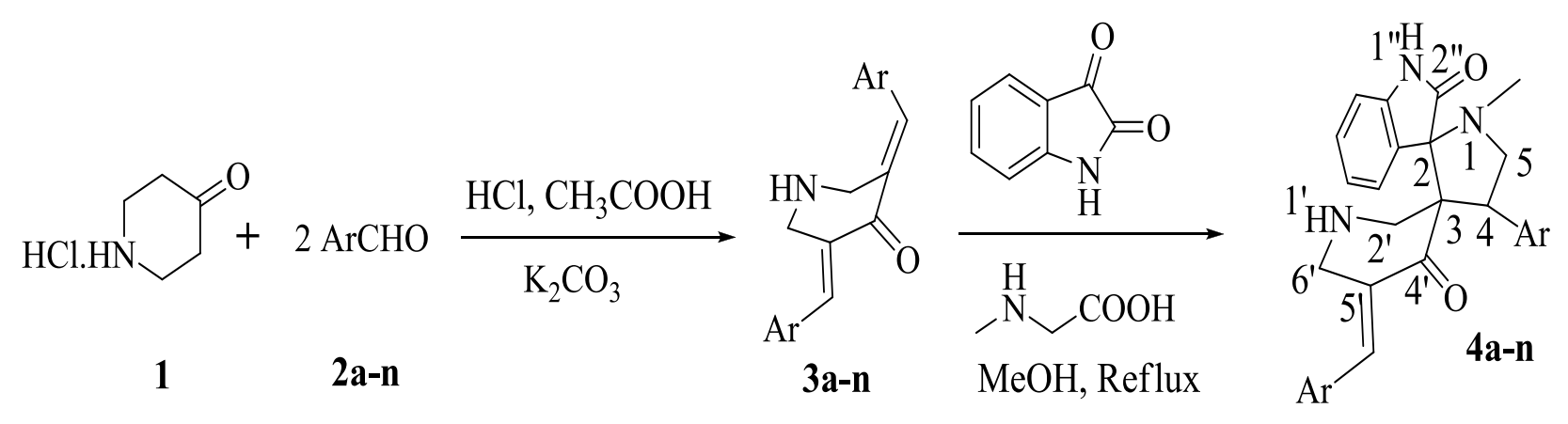

Ar : $\mathbf{a}=\mathrm{Ph} ; \mathbf{b}=2-\mathrm{MePh} ; \mathbf{c}=2-\mathrm{OMePh} ; \mathbf{d}=2-\mathrm{ClPh} ; \mathbf{e}=2-\mathrm{BrPh} ; \mathbf{f}=2-\mathrm{FPh} ; \mathbf{g}=2,4-\mathrm{Cl}_{2} \mathrm{Ph}$;

$\mathbf{h}=3-\mathrm{NO}_{2} \mathrm{Ph} ; \mathbf{i}=4-\mathrm{MePh} ; \mathbf{j}=4-\mathrm{OMePh} ; \mathbf{k}=4-\mathrm{ClPh} ; \mathbf{l}=4-\mathrm{BrPh} ; \mathbf{m}=4-\mathrm{FPh} ; \mathbf{n}=1-\mathrm{Naphthyl}$

Scheme 1: Synthesis of dispiro-pyrrolidines.
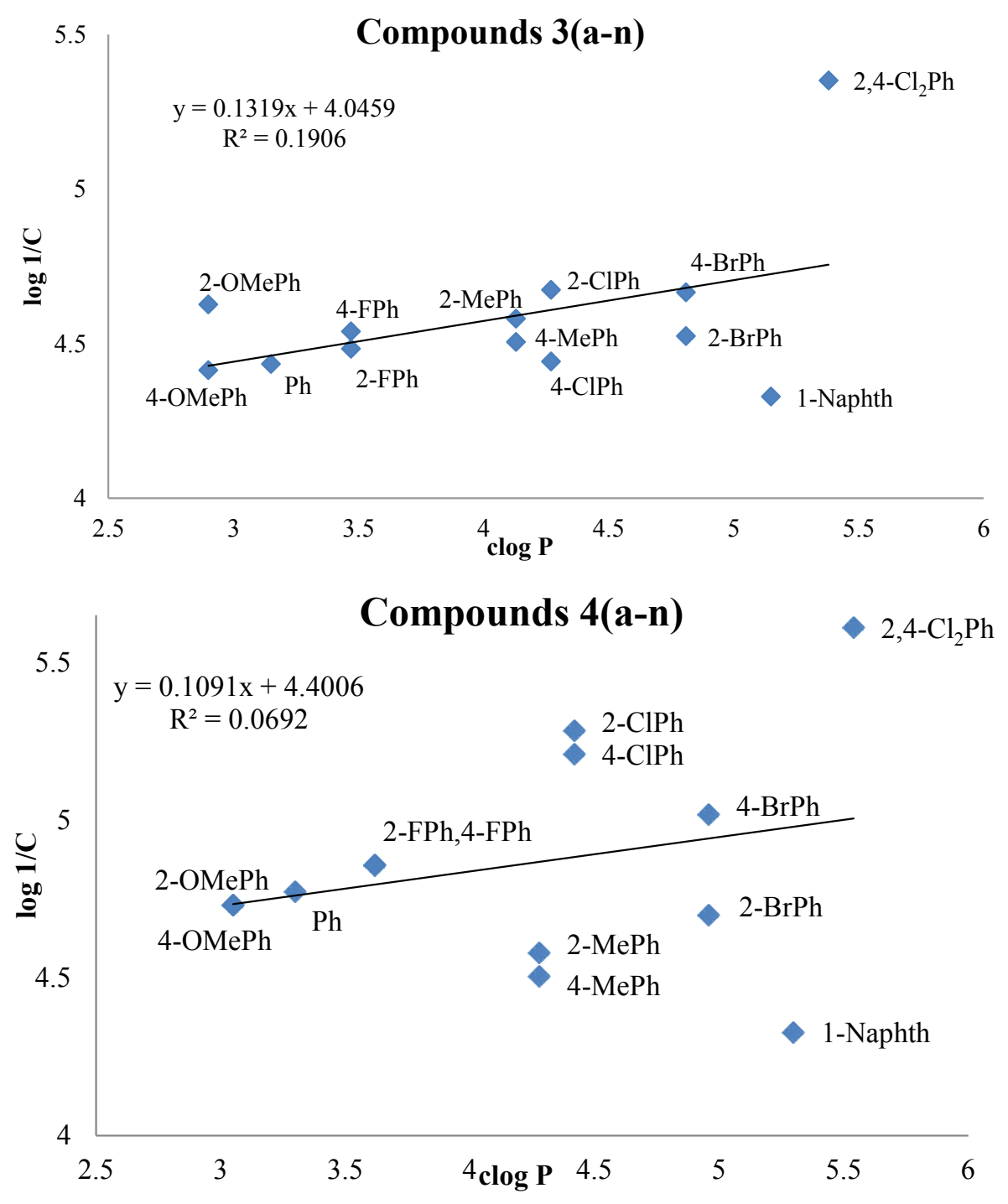

Figure 2: Correlation between $\log 1 / \mathrm{C}$ and clog $\mathrm{P}$. 
Citation: Hassan MZ, Ali MA, Osman H, Kumar RS, Arumugam N (2016) Design, Synthesis and Antimycobacterial Activity of Dispiropyrrolidines Derivatives. Med chem (Los Angeles) 6: 486-491. doi:10.4172/2161-0444.1000387

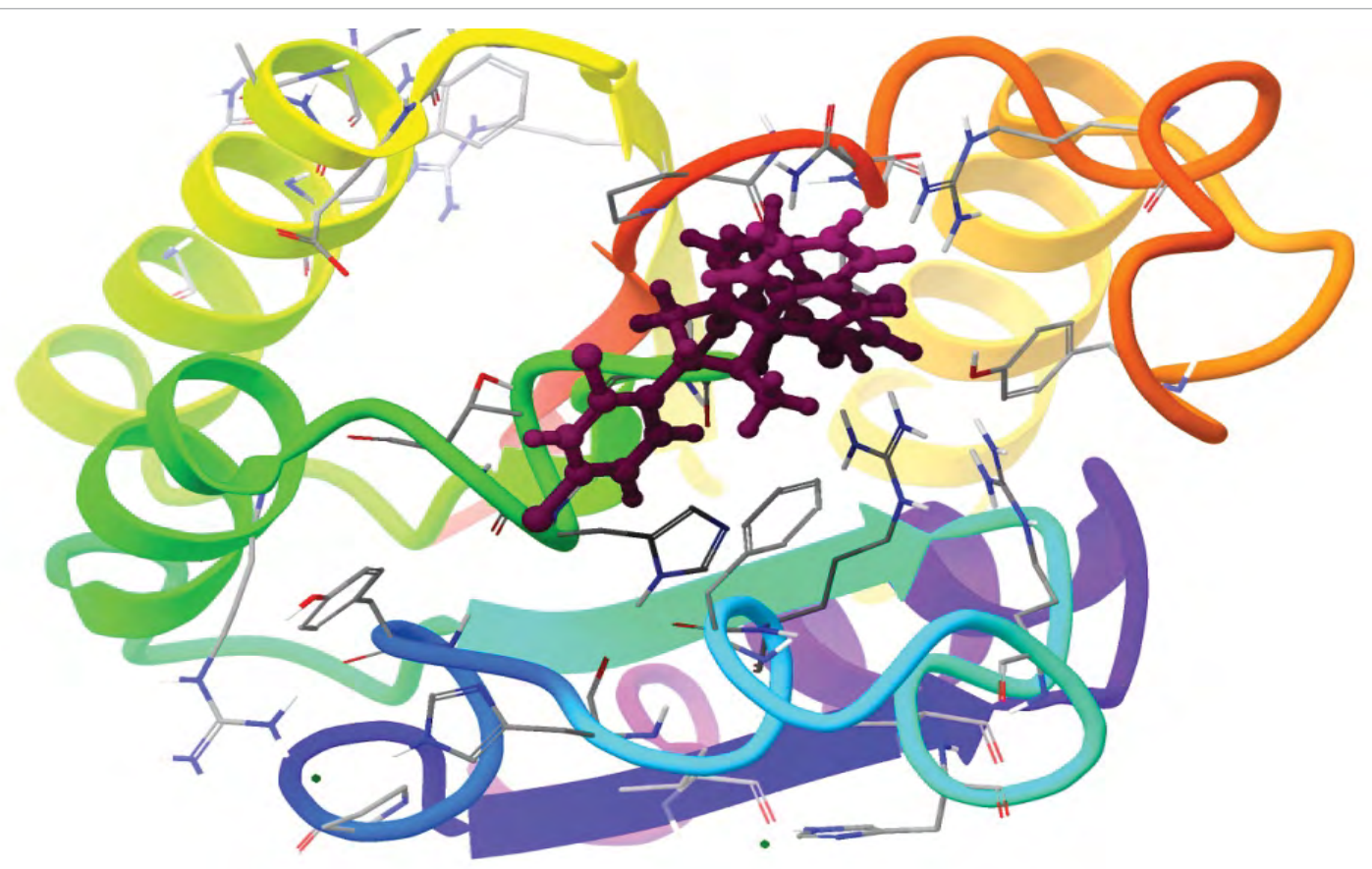

Figure 3: Compound 4g (ball and stick representation in purple) docked in Type II DHQase enzyme (PDB ID: 1HOR, secondary structure represenation).

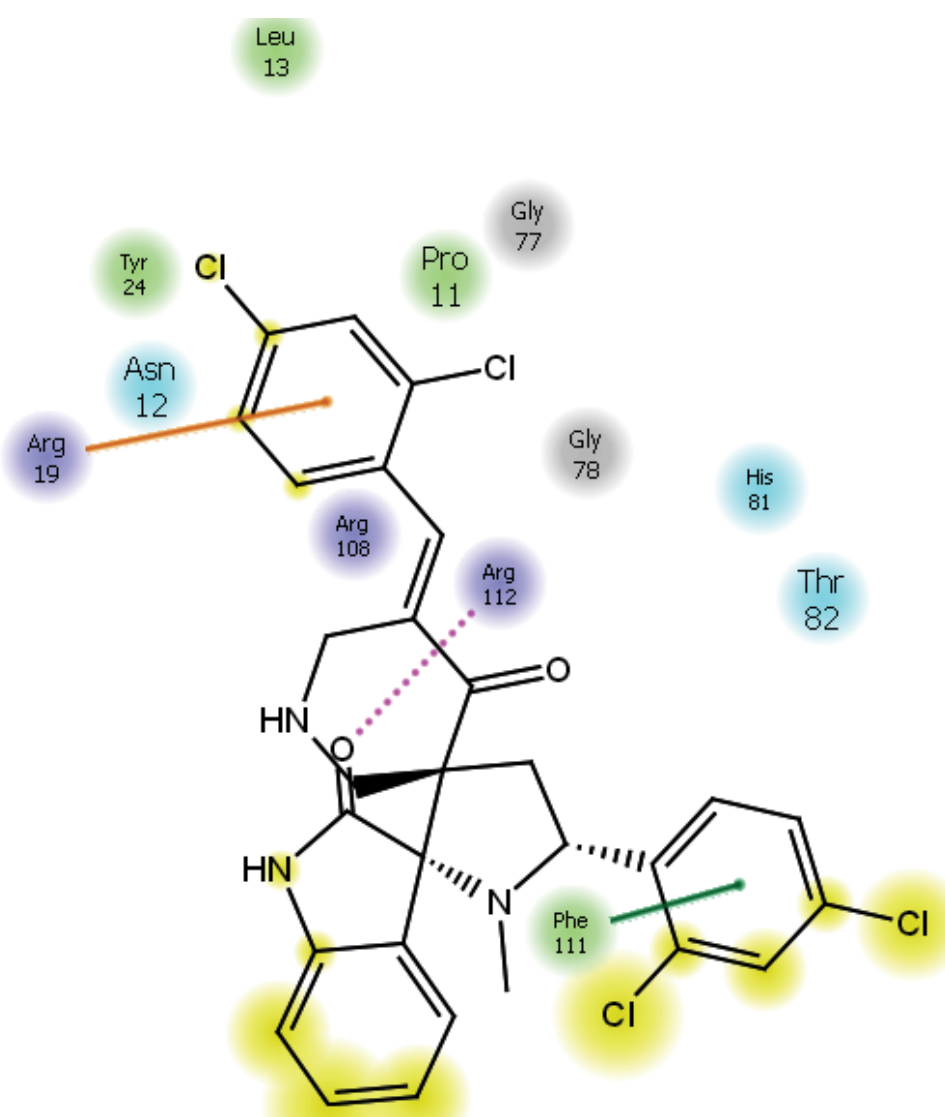

Figure 4: $2 \mathrm{D}$ ligand interaction diagram of $\mathbf{4 g}$ with active site residues of Type II DHQase (The dotted lines shows hydrogen bonding; brown solid line represents $\pi$-cation interaction; green solid line represents $\pi-\pi$ stacking). 
Citation: Hassan MZ, Ali MA, Osman H, Kumar RS, Arumugam N (2016) Design, Synthesis and Antimycobacterial Activity of Dispiropyrrolidines Derivatives. Med chem (Los Angeles) 6: 486-491. doi:10.4172/2161-0444.1000387

\begin{tabular}{|c|c|c|c|c|c|c|c|c|}
\hline \multirow{2}{*}{ S No } & \multirow{2}{*}{ Compounds } & \multirow{2}{*}{$\%$ Yields } & \multicolumn{3}{|c|}{ Antimycobacterial activity } & \multirow{2}{*}{$\begin{array}{c}\text { Cytotoxicity } \\
\mathrm{IC}_{50} \mu \mathrm{m} / \mathrm{ml}\end{array}$} & \multirow{2}{*}{$\log 1 / C^{a}$} & \multirow{2}{*}{$\operatorname{clog} \mathrm{P}^{\mathrm{b}}$} \\
\hline & & & $\mathrm{EC}_{50}(\mu \mathrm{M})$ & $\mathrm{EC}_{90}(\mu \mathrm{M})$ & MIC $(\mu \mathrm{M})$ & & & \\
\hline 1 & $3 a$ & 91 & 36.81 & 48.13 & 100.00 & $>62.5$ & 4.43 & 3.15 \\
\hline 2 & $3 b$ & 90 & 26.30 & 31.50 & 100.00 & $>62.5$ & 4.58 & 4.13 \\
\hline 3 & $3 c$ & 92 & 23.64 & 56.83 & 100.00 & $>62.5$ & 4.63 & 2.9 \\
\hline 4 & $3 d$ & 90 & 21.19 & 55.90 & 100.00 & $>62.5$ & 4.67 & 4.27 \\
\hline 5 & $3 e$ & 89 & 29.95 & 51.87 & 100.00 & $>62.5$ & 4.52 & 4.81 \\
\hline 6 & $3 f$ & 93 & 32.91 & 52.93 & 100.00 & $>62.5$ & 4.48 & 3.47 \\
\hline 7 & $3 g$ & 85 & 04.46 & 08.42 & 10.00 & $>62.5$ & 5.35 & 5.38 \\
\hline 8 & $3 \mathrm{~h}$ & 93 & 37.62 & 73.67 & 100.00 & $>62.5$ & 4.42 & $-c$ \\
\hline 9 & $3 i$ & 91 & 31.28 & 53.86 & 100.00 & $>62.5$ & 4.50 & 4.13 \\
\hline 10 & $3 \mathbf{j}$ & 94 & 38.57 & 62.72 & 100.00 & $>62.5$ & 4.41 & 2.9 \\
\hline 11 & $3 k$ & 90 & 36.18 & 54.97 & 100.00 & $>62.5$ & 4.44 & 4.27 \\
\hline 12 & 31 & 91 & 21.58 & 35.06 & 100.00 & $>62.5$ & 4.67 & 4.81 \\
\hline 13 & $3 m$ & 90 & 28.87 & 44.60 & 100.00 & $>62.5$ & 4.54 & 3.47 \\
\hline 14 & $3 n$ & 92 & 46.95 & 96.38 & $>100.00$ & $>62.5$ & 4.33 & 5.15 \\
\hline 15 & $4 a$ & 92 & 16.81 & 28.13 & 50.00 & $>62.5$ & 4.77 & 3.3 \\
\hline 16 & $4 b$ & 90 & 26.30 & 51.50 & 100.00 & $>62.5$ & 4.58 & 4.28 \\
\hline 17 & $4 c$ & 86 & 18.64 & 39.83 & 50.00 & $>62.5$ & 4.73 & 3.05 \\
\hline 18 & $4 d$ & 91 & 05.19 & 15.90 & 25.00 & $>62.5$ & 5.28 & 4.42 \\
\hline 19 & $4 e$ & 90 & 19.95 & 31.87 & 50.00 & $>62.5$ & 4.70 & 4.96 \\
\hline 20 & $4 f$ & 92 & 13.91 & 22.93 & 25.00 & $>62.5$ & 4.86 & 3.62 \\
\hline 21 & $4 g$ & 90 & 02.46 & 05.42 & 10.00 & $>62.5$ & 5.61 & 5.54 \\
\hline 22 & $4 \mathrm{~h}$ & 89 & 12.62 & 33.67 & 50.00 & $>62.5$ & 4.90 & - \\
\hline 23 & $4 i$ & 93 & 31.28 & 53.86 & 100.00 & $>62.5$ & 4.50 & 4.28 \\
\hline 24 & $4 j$ & 85 & 18.57 & 32.72 & 50.00 & $>62.5$ & 4.73 & 3.05 \\
\hline 25 & $4 k$ & 93 & 06.18 & 14.97 & 25.00 & $>62.5$ & 5.21 & 4.42 \\
\hline 26 & $4 I$ & 91 & 09.58 & 21.06 & 50.00 & $>62.5$ & 5.02 & 4.96 \\
\hline 27 & $4 m$ & 94 & 13.87 & 24.60 & 50.00 & $>62.5$ & 4.86 & 3.62 \\
\hline 28 & $4 n$ & 90 & 46.95 & 66.38 & 100.00 & $>62.5$ & 4.33 & 5.3 \\
\hline 29 & Amikacin $^{d}$ & - & 0.07 & 0.08 & 0.16 & $>62.5$ & - & - \\
\hline 30 & Cycloserine & - & 12.47 & 13.49 & 25.00 & $>62.5$ & - & - \\
\hline 31 & Ethambutol & - & $<1.56$ & 32.79 & 12.50 & $>62.5$ & - & - \\
\hline 32 & Isoniazid & - & 0.18 & 0.29 & 0.31 & $>62.5$ & - & - \\
\hline 33 & Pyrimethamine & - & 37.35 & 74.96 & 100.00 & $>62.5$ & - & - \\
\hline
\end{tabular}

${ }^{\mathrm{a} C}$ represents the molar concentration $\left(\mathrm{EC}_{50}\right)$; ${ }^{\mathrm{b} C a l c u l a t e d} \log \mathrm{P}(\mathrm{clog} \mathrm{P})$ values were calculated from the software ChemDraw Ultra $11.0 ;{ }^{\mathrm{c}} \mathrm{dash}(-)$ indicates not calculated dStandard antitubercular drugs.

Table 1: HTS antimycobacterial activity and cytotoxicity of 3a-n and 4a-n.

Tyr24, Asn75, Gly77, Gly78, His81, His101, Ile102, Ser103, Arg108 and Arg112. Results showed that, compound $\mathbf{4 g}$ docked essentially at the same binding pocket as the native ligand in the crystal structure, by forming hydrogen bonding, polar and hydrophobic interactions with amino acids in the active site. The substituent 2,4-dichlorophenyl formed $\pi-\pi$ stacking with Phe $111(1.816 \AA)$ and $\pi$-cation interaction with Arg 19 (2.911 $\AA$ ). This is corroborated well by the predicted SAR that, the disubstitutions with chloro group at the phenyl ring resulted into more active compounds. Compound $4 \mathrm{~g}$ also displayed hydrophobic interactions with Pro11, Leu 13, Tyr 24 and Phe 111. Other than the important residues in the active site, there is additionally hydrogen bonding formed between the oxygen atom of indolin-2-one and Arg 112 at a distance of $1.966 \AA$. Thus the antimycobacterial effects of dispiropyrrolidines derivatives might be due to inhibition of enzyme Type II DHQase.

\section{Conclusion}

In summary, we have reported the antimycobacterial activities of a series of piperidone substituted dispiropyrrolidine. The results of preliminary antimycobacterial evaluation showed that, compound 4g, 1-Methyl-4-(2,4-dichlorophenyl)pyrrolo-(spiro[2.3"]oxindole)- spiro[3.3']-5'-(2,4-dichloro-benzylmethyl-idene)piperidin-4'-one emerged as a lead compound having prominent antimycobacterial activity without any cytotoxic effect. Thus the series provided new opportunities for possible modification and future exploitation to get the derivatives having better potency than the currently available drugs.

\section{Acknowledgements}

The authors wish to express their gratitude and appreciation to School of Chemical Science, Universiti Sains Malaysia, Penang, Malaysia for supporting this work. This work was funded through Research Grant No. FRGS/203/6711462.

\section{References}

1. Rappuoli $R$ (2104) Changing route: aerosol vaccine against tuberculosis. Lanc Infect Dis 14: 901-902.

2. Global tuberculosis report (2015) World Health Organisation.

3. Fogel N (2015) Tuberculosis: A disease without boundaries. Tuber 95: 527531.

4. Keshavjee S, Farmer P (2012) Tuberculosis, drug, resistance, and the history of modern medicine. N Engl J Med 367: 931-936.

5. CDC (2016) Treatment of tuberculosis. American Thoracic Society, CDC, and Infectious Diseases Society of America. MMWR 2003 52: 1-77. 
Citation: Hassan MZ, Ali MA, Osman H, Kumar RS, Arumugam N (2016) Design, Synthesis and Antimycobacterial Activity of Dispiropyrrolidines Derivatives. Med chem (Los Angeles) 6: 486-491. doi:10.4172/2161-0444.1000387

6. Kana BD, Karakousis PC, Parish T, Dick T (2014) Future target-based drug discovery for tuberculosis. Tuber 94: 551-556.

7. Pervez H, Iqbal MS, Tahir MY, Nasim FH, Choudhary MI, et al. (2008) In vitro cytotoxic, antibacterial, antifungal and urease inhibitory activities of some $\mathrm{N}^{4}$ substituted isatin-3-thiosemicarbazones. J Enz Inhib Med Chem 23: 848-854.

8. Ke S, Shi L, Yang Z (2015) Discovery of novel isatin-dehydroepiandrosterone conjugates as potential anticancer agents. Bioorg Med Chem Lett 25: 46284631.

9. Aboul-Fadl T, Mohammed FA, Hassan EA (2003) Synthesis, antitubercular activity and pharmacokinetic studies of some Schiff bases derived from 1-alkylisatin and isonicotinic acid hydrazide (INH). Arch Pharm Res 26: 778784

10. Marti C, Carreira EM (2003) Construction of Spiro[pyrrolidine-3,3-oxindoles] Recent Applications to the Synthesis of Oxindole Alkaloids. Eur J Org Chem 2003: 2209-2219.

11. Rouatbi F, Askri M, Nana F, Kirsch G, Sriram D, et al. (2016) Synthesis of new spirooxindole derivatives through 1,3-dipolar cycloaddition of azomethine ylides and their antitubercular activity. Tetrahed Lett 57: 163-167.

12. Wei AC, Ali MA, Yoon YK, Ismail R, Choon TS, et al. (2013) A facile threecomponent [3+2]-cycloaddition for the regioselective synthesis of highly functionalised dispiropyrrolidines acting as antimycobacterial agents. Bioorg Med Chem Lett 23: 1383-1386.

13. Wei AC, Ali MA, Yoon YK, Ismail R, Choon TS, et al. (2012) Antimycobacterial activity: A facile three-component [3+2]-cycloaddition for the regioselective synthesis of highly functionalised dispiropyrrolidines. Bioorg Med Chem Lett 22: $4930-4933$
14. Ali MA, Ismail R, Choon TS, Kumar RS, Osman H, et al. (2012) AChE inhibitor A regio- and stereo-selective 1,3-dipolar cycloaddition for the synthesis of novel substituted 5,6-dimethoxy spiro[5.3']-oxindole-spiro-[6.3"]-2,3-dihydro$1 \mathrm{H}$-inden-1"-one-7-(substituted aryl)-tetrahydro-1H-pyrrolo[1,2-c][1,3]thiazole. Bioorg Med Chem Lett 22: 508-511.

15. Almansour Al, Kumar RS, Beevi F, Shirazi AN, Osman H, et al. (2014) Facile, regio- and diastereoselective synthesis of spiro-pyrrolidine and pyrrolizine derivatives and evaluation of their antiproliferative activities. Molecules 19: 10033-10055.

16. Collins L, Franzblau SG (1997) Microplate alamar blue assay versus BACTEC 460 system for high-throughput screening of compounds against Mycobacterium tuberculosis and Mycobacterium avium. Antimicro Agent Chemo 41: 1004-1009.

17. Biosafety in Microbiological and Biomedical Laboratories (BMBL) (2009) 5th edn. US Department of Health and Human Services.

18. Campling BG, Pym J, Galbraith PR, Cole SPC (1988) Use of the MTT assay for rapid determination of chemosensitivity of human leukemic blast cells. Leuk Res 12: 823-831.

19. Tanaka A, Nakamura K, Nakanishi I, Fujiwara H (1994) A Novel and Useful Descriptor for Hydrophobicity, Partition Coefficient Micellar-Water, and Its Application to a QSAR Study of Antiplatelet Agents. J Med Chem 37: 45634566

20. El-Din GA, Abuo-Rahma A, Sarhan HA, Gad GFM (2009) Design, synthesis antibacterial activity and hysicochemical parameters of novel N-4-piperazinyl derivatives of Norfloxacin. Bioorg Med Chem 17: 3879-3886.

21. Dias MVB, Snee WC, Bromfield KM, Payne RJ, Palaninathan SK, et al (2011) Structural investigation of inhibitor designs targeting 3-dehydroquinate dehydratase from the shikimate pathway of Mycobacterium tuberculosis. Biochem J 436: 729-739. 